\author{
Kyong Soo Park · Hyoung Doo Shin · Byung Lae Park \\ Hyun Sub Cheong · Young Min Cho · Hong Kyu Lee \\ Jong-Young Lee $\cdot$ Jong-Keuk Lee $\cdot$ Bermseok Oh \\ Kuchan Kimm
}

\title{
Polymorphisms in the leptin receptor (LEPR)—putative association with obesity and T2DM
}

Received: 24 August 2005/ Accepted: 6 October 2005/Published online: 7 December 2005

(C) The Japan Society of Human Genetics and Springer-Verlag 2005

\begin{abstract}
Leptin plays an important role in regulating adipose-tissue mass. Leptin controls energy balance and food intake through the leptin receptor in the hypothalamus of the brain, which suggests that some polymorphisms of the leptin receptor gene (LEPR) might contribute to obesity or obesity-related diseases. In an effort to identify genetic polymorphisms in a potential candidate gene for obesity and type 2 diabetes mellitus (T2DM) in the Korean population, we have sequenced the $L E P R$ gene. Thirty-five sequence variants were identified (including 9 novel polymorphisms): 1 single nucleotide polymorphism (SNP) in the promoter region, $1 \mathrm{SNP}$ in the $5^{\prime}$ UTR, 8 SNPs in exons (3 non-synonymous SNPs), 23 SNPs in introns, 1 ins/del in the $3^{\prime}$ UTR, and $1 \mathrm{SNP}$ in the $3^{\prime}$ downstream region. To investigate possible association of $L E P R$ polymorphisms with body mass index (BMI) and the risk of T2DM, we genotyped for 11 polymorphisms in the Korean population
\end{abstract}

Electronic Supplementary Material Supplementary material is available for this article at http://dx.doi.org/10.1007/s10038-005$0327-8$ and is accessible for authorized users.

Kyong Soo Park and Hyoung Doo Shin contributed equally to this work

K.S. Park · Y.M. Cho · H.K. Lee

Genome Research Center for Diabetes and Endocrine Disease, Clinical Research Institute, Seoul National University Hospital, Department of Internal Medicine, Seoul National University College of Medicine, 110-744 Seoul, Korea

H.D. Shin · B.L. Park · H.S. Cheong

Department of Genetic Epidemiology, SNP Genetics, Rm 1407, 14th floor, B-dong, WooLim Lion's Valley, 371-28, Gasan-dong, Geumcheon-Gu, 153-803 Seoul, Korea

J.-Y. Lee $\cdot$ J.-K. Lee $\cdot$ B. Oh $\cdot$ K. Kimm $(\bowtie)$

National Genome Research Institute, National Institute of Health, 5 Nokbun-dong, Eunpyung-ku, 122-701 Seoul, Korea

E-mail: k2kimm2@nih.go.kr

Tel.: + 82-2-3801522

Fax: $+82-2-3541063$ $(n=1,463)$. Using statistical analyses, no significant associations between the genetic polymorphisms in the $L E P R$ gene and the risk of T2DM were detected. However, one non-synonymous SNP in exon 3, $+5193 \mathrm{G}>\mathrm{A}$ (Arg109Lys), showed marginal association with BMI $(P=0.02)$ and gene dose-dependent genetic effects were observed. The present study provides information about additional genetic polymorphisms in $L E P R$ and positive associations of those polymorphisms with BMI in the Korean population.

Keywords Body mass index - Leptin receptor . Obesity · Type 2 diabetes

\section{Introduction}

Leptin (LEP) is a well known anti-obesity hormone that regulates body weight through its effects on food intake and energy expenditure (Zhang et al. 1994; Halaas et al. 1995; Pelleymounter et al. 1995). The leptin receptor (LEPR) is a single transmembrane protein belonging to the superfamily of cytokine receptors, and has several alternatively spliced isoforms that are distributed in many types of tissue (Tartaglia et al. 1995; Woods and Stock 1996; Friedman and Halaas 1998; Mantzoros and Flier 2000). Leptin and its receptor are known to play a role in glucose metabolism. For instance, leptin exerts insulin- and glucose-lowering effects by enhancing peripheral insulin sensitivity and glucose uptake (Cohen et al. 1996; Berti et al. 1997; Sivitz et al. 1997; Aiston and Agius 1999; Ceddia et al. 1999; Fukuda et al. 1999). In addition, leptin receptors are present on pancreatic betacells, which could offer one mechanism by which leptin could modulate glucose-induced insulin secretion (Kieffer et al. 1996, 1997; Emilsson et al. 1997).

Obesity occurs due to the combined effects of genes, environment, lifestyle, and the interactions of these factors (Bouchard 1994; Mantzoros 1999). Leptin levels 
increase with increasing amounts of fat mass (Maffei et al. 1995; Considine et al. 1996), suggesting that obesity is a leptin-resistant state in humans. Therefore, it could be suggested that genetic variation at the $L E P R$ locus and/or postreceptor defects may play a significant role in type 2 diabetes mellitus (T2DM) and the pathophysiology of human obesity.

Since the LEPR has a functional importance for obesity, a number of studies of LEPR association with obesity and/or obesity-related diseases have been performed to date. Two non-synonymous polymorphisms in LEPR have mainly been examined (Arg109Lys in exon 3 and Arg223Gln in exon 5), e.g., lower body mass index (BMI) associated with Arg109 homozygotes in the Swedish population (Rosmond et al. 2000); higher weight gain and leptin levels associated with the Arg109 or the Arg223 alleles in the Dutch population (van Rossum et al. 2003); insulin sensitivity index and glucose clearance associated with Arg223Gln polymorphism (Chiu et al. 2004); higher insulin levels associated with higher prevalence of the Gln223 allele in the Mexican population (Guizar-Mendoza et al. 2005); and higher leptin levels associated with a Lys109Arg or Gln223Arg mutation in young Dutch adults (van Rossum et al. 2003).

In the present study, we re-sequenced the $-1,5005^{\prime}$ flanking region and all exons, including $+/-50 \mathrm{bp}$ exon-intron boundaries, to discover additional polymorphisms in $L E P R$, and examined the genetic association with the risk of T2DM and diabetic phenotypes in the Korean population $(n=1,463)$.

\section{Materials and methods}

Subjects and measurements

A total of 775 unrelated patients with T2DM and 688 unrelated nondiabetic control subjects were recruited. Nondiabetic control subjects were recruited from an unselected population undergoing a routine health checkup at Seoul National University Hospital. Inclusion criteria were as follows: 60 or more years of age, no past history of diagnosis of diabetes, no diabetes in first-degree relatives, fasting plasma glucose level less than $6.1 \mathrm{mmol} / \mathrm{l}$, and HbAlc less than $5.8 \%$. The diabetic subjects were randomly recruited from patients attending the outpatient clinic of Seoul National University Hospital, Seoul, Korea. Diabetes was diagnosed based on American Diabetes Association (ADA) criteria (The expert committee on the diagnosis and classification of diabetes mellitus 1997). Subjects positive for glutamate decarboxylase (GAD) antibodies were excluded. All subjects enrolled in this study were of Korean ethnicity. The study protocol was approved by the Institutional Review Board of the Clinical Research Institute at Seoul National University Hospital. Informed consent was obtained from all subjects before drawing blood. All study subjects were examined in the morning after an overnight fast. Height, weight, circumferences of waist and hip, and blood pressure were measured. Blood samples were drawn for biochemical measurements [fasting plasma glucose, postprandial 2-h glucose, fasting plasma insulin, HbA1c, total cholesterol, triglyceride, and high-density lipoprotein (HDL) cholesterol] and DNA extraction. The insulin resistance index $\mathrm{HOMA}_{\mathrm{IR}}$ (homeostasis model assessment) was calculated as fasting serum insulin $(\mathrm{pmol} / \mathrm{l}) \times$ fasting plasma glucose (mmol/1)/135 (Matthews et al. 1985). The clinical characteristics of the subjects are shown in Table 1.

Sequencing analysis of the human $L E P R$ gene

We sequenced all exons, including exon-intron boundaries and the promoter region $(\sim 1.5 \mathrm{~kb})$, to discover single nucleotide polymorphisms (SNPs) in 24 Korean DNA samples using an ABI PRISM 3700 DNA analyzer (Applied Biosystems, Foster City, CA). Twentytwo primer sets for amplification and sequence analysis were designed based on GenBank sequences (accession numbers: LEPR mRNA NM_002303 and genomic sequence NT_032977). Information regarding primers is available at http://www.snp-genetics.com/reference/ Supplementary information to LEPR.doc Sequence variants were verified by chromatograms.
Table 1 Clinical profiles of type 2 diabetic patients and normal controls $(n=1,463)$. Data are means \pm SD. T2DM Type 2 diabetes mellitus, $B M I$ body mass index, HOMA-IR homeostasis model assessment of insulin resistance

$* P<0.001, * * P<0.01$ for difference between T2DM and normal controls

\begin{tabular}{lcc}
\hline Features & T2DM patients & Normal controls \\
\hline Sex (M/F) & $361 / 414$ & $308 / 380$ \\
Age (years) & $58.9 \pm 10.5$ & $64.2 \pm 4.2$ \\
BMI (kg/m $)^{*}$ & $24.4 \pm 2.9$ & $23.6 \pm 3.1$ \\
Waist-to-hip ratio & $0.9 \pm 0.1$ & $0.9 \pm 0.1$ \\
Systolic blood pressure (mmHg) & $134.5 \pm 20$ & $128.3 \pm 19.3$ \\
Diastolic blood pressure (mmHg) & $80.8 \pm 11.9$ & $79.7 \pm 11$ \\
HOMA-IR* & $4.7 \pm 4.7$ & $1.8 \pm 1$ \\
Total cholesterol (mg/dl) & $199.1 \pm 37.5$ & $193.1 \pm 34.8$ \\
Triglyceride (mg/dl)* & $171.2 \pm 116.9$ & $128.8 \pm 65.4$ \\
HDL cholesterol (mg/dl)** & $47.5 \pm 11.7$ & $46.1 \pm 12.7$ \\
Fasting blood glucose $(\mathrm{mg} / \mathrm{dl})^{*}$ & $155.1 \pm 47.5$ & $90.3 \pm 11$ \\
HBA1C $(\%)^{*}$ & $8.1 \pm 1.6$ & $5.3 \pm 0.4$
\end{tabular}


Genotyping with fluorescence polarization detection

For genotyping of polymorphic sites, amplifying primers and probes were designed for TaqMan (Livak 1999). Primer Express (Applied Biosystems) was used to design both the PCR primers and the MGB TaqMan probes. One allelic probe was labeled with the FAM dye and the other with the fluorescent dye VIC. PCR was carried out in TaqMan Universal Master mix without UNG (Applied Biosystems), with PCR primer concentrations of $900 \mathrm{nM}$ and TaqMan MGB-probe concentrations of 200 $\mathrm{nM}$. Reactions were performed in a 384-well format in a total reaction volume of $5 \mu \mathrm{l}$ using $20 \mathrm{ng}$ genomic DNA. The plates then were placed in a thermal cycler $(\mathrm{PE}$ 9700, Applied Biosystems) and heated at $50^{\circ} \mathrm{C}$ for $2 \mathrm{~min}$ and $95^{\circ} \mathrm{C}$ for $10 \mathrm{~min}$, followed by 40 cycles of $95^{\circ} \mathrm{C}$ for $15 \mathrm{sec}$ and $60^{\circ} \mathrm{C}$ for $1 \mathrm{~min}$. The TaqMan assay plates were transferred to a Prism 7900HT instrument (Applied Biosystems) where the fluorescence intensity in each well of the plate was read. Fluorescence data files from each plate were analyzed using automated software (SDS 2.1). Information regarding the primers is available on our website (http://www.snp-genetics.com/reference/ Supplementary information to LEPR.doc).

\section{Statistics}

To determine whether each individual variant was in equilibrium at each locus in the population (HardyWeinberg equilibrium), $\chi^{2}$ tests were used. Haplotypes and their frequencies were inferred using the algorithm developed by Stephens and co-workers (Considine et al. 1996). Logistic regression analyses were used for calculating $P$-values, controlling for age, BMI, and sex as covariates. Multiple regressions while adjusting for age and sex were used for association analyses of metabolic phenotypes. Haplotype associations were analyzed using the algorithm developed by Schaid et al. (Haplo.Score and Haplo.GLM; Schaid et al. 2002), controlling for age and sex as covariates. Only nondiabetic subjects were used for association analyses of BMI, as treatment of T2DM may have affected BMI in diabetics.

\section{Results}

To discover polymorphisms, we sequenced all exons and their boundaries, including $1.5 \mathrm{~kb}$ upstream of the $L E P R$ gene, with 24 unrelated Korean DNA samples.

a Map of $L E P R$ (leptin receptor) on chromosome 1 p31 (212.2 kb)
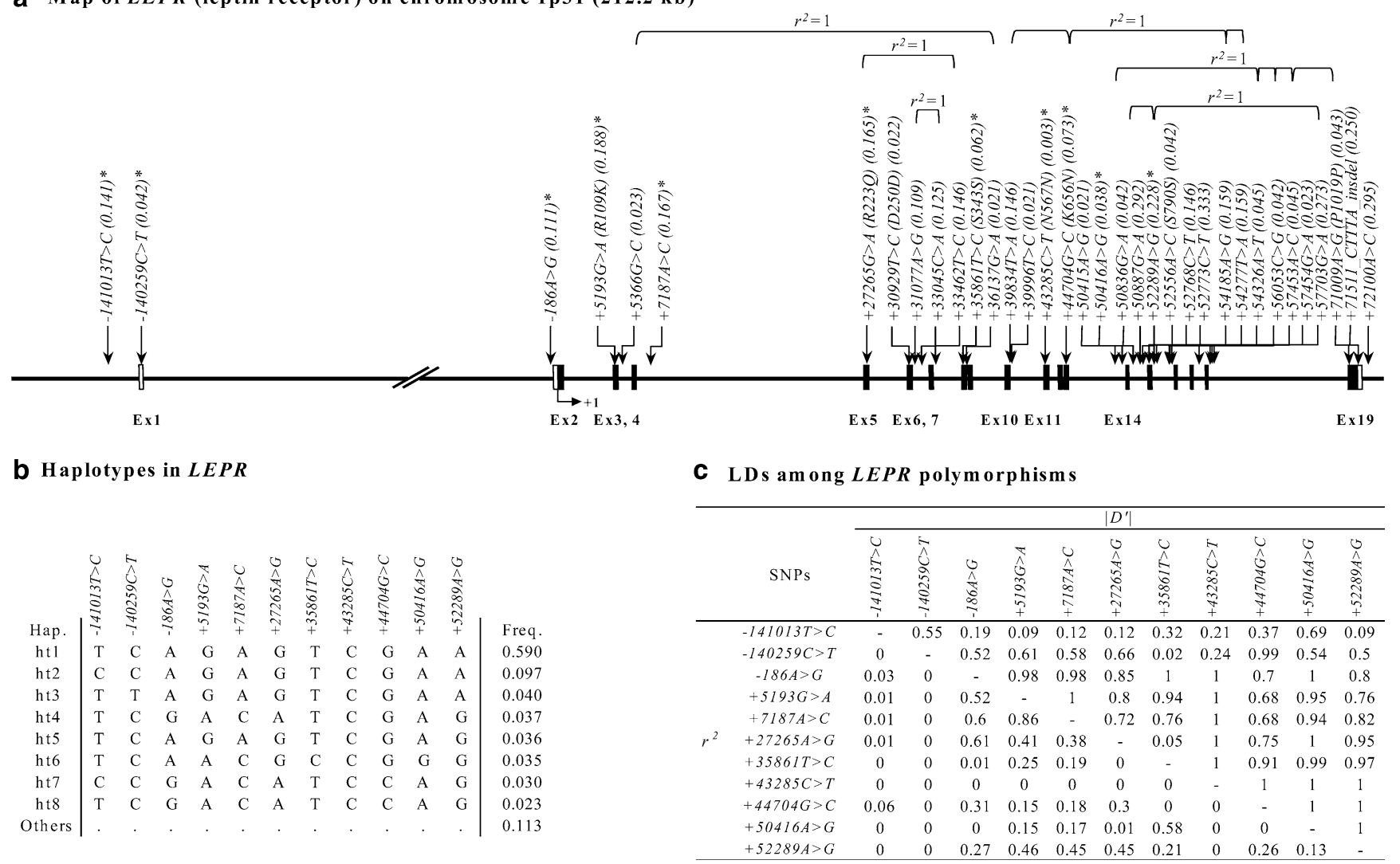

Fig. 1a-c Gene map and haplotypes of the leptin receptor gene (LEPR). Black blocks Coding exons, white blocks $5^{\prime}$ and $3^{\prime}$ UTRs, +1 first base of the translational start site, asterisks polymorphisms genotyped in a larger population $(n=1,463)$. The frequencies of polymorphisms not subjected to larger-scale genotyping

were based on sequence data $(n=24)$. a Polymorphisms identified in LEPR on chromosome 1p31 (accession no. NT_032977). b $L E P R$ haplotypes. Only those with frequencies $>0.02$ are shown. c Linkage disequilibrium (LD) coefficients $\left(\left|\mathrm{D}^{\prime}\right|\right.$ and $\left.r^{2}\right)$ among $L E P R$ polymorphisms 
We identified 35 sequence variants (including 9 novel polymorphisms): $1 \mathrm{SNP}$ in the promoter region, $1 \mathrm{SNP}$ in the $5^{\prime}$ UTR, 8 SNPs (including 3 non-synonomous SNPs) in coding sequences, 23 SNPs in introns, 1 ins/del in the $3^{\prime}$ UTR, and 1 SNP in the 3' downstream region. The location of these polymorphisms in relation to the genomic structure of the $L E P R$ gene is shown in Fig. 1a. No deviations from Hardy-Weinberg equilibrium were observed [see Table S1 (Supplementary Material)]. By pair-wise linkage analysis among polymorphisms, we have found that six sets of SNPs were in absolute linkage disequilibrium (LD) $\left(\left|\mathrm{D}^{\prime}\right|=1\right.$ and $r^{2}=1$; Fig. 1a). Eleven SNPs $[-141013 \mathrm{~T}>\mathrm{C}, \quad-140259 \mathrm{C}>\mathrm{T}, \quad-186 \mathrm{~A}>\mathrm{G}$, $+5193 \mathrm{G}>\mathrm{A}(\operatorname{Arg} 109 \mathrm{Lys}),+7187 \mathrm{~A}>\mathrm{C},+27265 \mathrm{G}>\mathrm{A}$ $(\operatorname{Arg} 223 \mathrm{Gln}),+35861 \mathrm{~T}>\mathrm{C}(\mathrm{Ser} 343 \mathrm{Ser}),+43285 \mathrm{C}>\mathrm{T}$ $($ Asn567Asn $),+44704 \mathrm{G}>\mathrm{C}($ Lys656Asn $),+50416 \mathrm{~A}>\mathrm{G}$ and $+52289 \mathrm{~A}>\mathrm{G}]$ were selected for larger-scale genotyping based on LDs, position, frequencies, and haplotype tagging status. Eight haplotypes (frequency $>0.02$ ) were constructed by 11 SNPs (Fig. 1b), and coefficients of linkage disequilibrium, $\left(\left|\mathrm{D}^{\prime}\right|\right)$ and $r^{2}$, of all pair-wise SNPs were also calculated (Fig. 1c). Information regarding frequencies, heterozygosity, and HardyWeinberg equilibrium is shown in Table S1. Among common haplotypes identified in the Korean population, those with frequencies greater than 0.05 were used for further analysis.

Associations of $L E P R$ polymorphisms with the risk of T2DM and BMI were analyzed using logistic and multiple regressions, while adjusting for age and sex (775 T2DM patients and 688 normal subjects) as covariates. As a result, we found that two polymorphisms, $+35861 \mathrm{~T}>\mathrm{C}$ (Ser343Ser) in exon 8 and $+50416 \mathrm{~A}>\mathrm{G}$ in intron 13 , were marginally associated with increased risk of T2DM $(P=0.05$ and 0.05 , respectively, Table 2$)$, and that one non-synonymous SNP in exon 3,
Table 2 Logistic analysis of leptin receptor gene ( $L E P R)$ polymorphisms controlling for age, BMI, and sex as covariates among type 2 diabetes mellitus (T2DM) patients and normal controls. Genotype distributions and $P$-values for logistic analyses of codominant model controlling for age, BMI, and sex as covariates are shown. $P$-values of haplotype associations were calculated using the algorithm developed by Schaid et al. (Haplo.Score), while controlling for age, BMI, and sex as covariates. Haplotypes with frequency $>0.05$ are presented

\begin{tabular}{|c|c|c|c|c|c|c|}
\hline Locus & Position & AA change & Genotype & Case $(n=775)$ & Control $(n=688)$ & $P$ \\
\hline$-141013 \mathrm{~T}>\mathrm{C}$ & Promoter & & $\begin{array}{l}\mathrm{T} \\
\mathrm{CT} \\
\mathrm{C}\end{array}$ & $\begin{array}{c}562(73.6 \%) \\
185(24.2 \%) \\
17(2.2 \%)\end{array}$ & $\begin{array}{c}507(74.3 \%) \\
161(23.6 \%) \\
14(2.1 \%)\end{array}$ & 0.94 \\
\hline$-140259 \mathrm{C}>\mathrm{T}$ & $5^{\prime}$ UTR & & $\begin{array}{l}\mathrm{C} \\
\mathrm{CT} \\
\mathrm{T}\end{array}$ & $\begin{array}{c}698(91.0 \%) \\
68(8.9 \%) \\
1(0.1 \%)\end{array}$ & $\begin{array}{c}631(92.5 \%) \\
50(7.3 \%) \\
1(0.2 \%)\end{array}$ & 0.36 \\
\hline$-186 \mathrm{~A}>\mathrm{G}$ & Intron 1 & & $\begin{array}{l}\text { A } \\
\text { AG } \\
G\end{array}$ & $\begin{array}{c}606(78.7 \%) \\
153(19.9 \%) \\
11(1.4 \%)\end{array}$ & $\begin{array}{c}543(79.4 \%) \\
136(19.9 \%) \\
5(0.7 \%)\end{array}$ & 0.34 \\
\hline$+5193 \mathrm{G}>\mathrm{A}$ & Exon 3 & Arg109Lys & $\begin{array}{l}\mathrm{G} \\
\mathrm{AG} \\
\mathrm{A}\end{array}$ & $\begin{array}{c}496(64.8 \%) \\
238(31.1 \%) \\
31(4.1 \%)\end{array}$ & $\begin{array}{c}461(67.5 \%) \\
200(29.3 \%) \\
22(3.2 \%)\end{array}$ & 0.21 \\
\hline$+7187 \mathrm{~A}>\mathrm{C}$ & Intron 4 & & $\begin{array}{l}\mathrm{A} \\
\mathrm{AC} \\
\mathrm{C}\end{array}$ & $\begin{array}{r}514(67.3 \%) \\
226(29.6 \%) \\
24(3.1 \%)\end{array}$ & $\begin{array}{c}488(71.4 \%) \\
183(26.8 \%) \\
13(1.9 \%)\end{array}$ & 0.06 \\
\hline$+27265 \mathrm{G}>\mathrm{A}$ & Exon 5 & Arg223Gln & $\begin{array}{l}\mathrm{G} \\
\mathrm{AG} \\
\mathrm{A}\end{array}$ & $\begin{array}{c}578(75.5 \%) \\
177(23.1 \%) \\
11(1.4 \%)\end{array}$ & $\begin{array}{c}523(76.5 \%) \\
148(21.6 \%) \\
13(1.9 \%)\end{array}$ & 0.89 \\
\hline$+35861 \mathrm{~T}>\mathrm{C}$ & Exon 8 & Ser343Ser & $\begin{array}{l}\mathrm{T} \\
\mathrm{CT} \\
\mathrm{C}\end{array}$ & $\begin{array}{c}659(86.0 \%) \\
103(13.5 \%) \\
4(0.5 \%)\end{array}$ & $\begin{array}{c}616(90.3 \%) \\
63(9.2 \%) \\
3(0.4 \%)\end{array}$ & 0.05 \\
\hline$+43285 \mathrm{C}>\mathrm{T}$ & Exon 11 & Asn567Asn & $\begin{array}{l}\mathrm{C} \\
\mathrm{CT} \\
\mathrm{T}\end{array}$ & $\begin{array}{c}769(99.6 \%) \\
3(0.4 \%) \\
0(0.0 \%)\end{array}$ & $\begin{array}{c}676(99.0 \%) \\
7(1.0 \%) \\
0(0.0 \%)\end{array}$ & 0.17 \\
\hline$+44704 \mathrm{G}>\mathrm{C}$ & Exon 13 & Lys656Asn & $\begin{array}{l}\text { G } \\
\mathrm{CG} \\
\mathrm{C}\end{array}$ & $\begin{array}{c}650(85.0 \%) \\
111(14.5 \%) \\
4(0.5 \%)\end{array}$ & $\begin{array}{r}596(87.3 \%) \\
84(12.3 \%) \\
3(0.4 \%)\end{array}$ & 0.25 \\
\hline$+50416 \mathrm{~A}>\mathrm{G}$ & Intron 13 & & $\begin{array}{l}\text { A } \\
\text { AG } \\
\text { G }\end{array}$ & $\begin{array}{c}698(90.9 \%) \\
70(9.1 \%) \\
0(0.0 \%)\end{array}$ & $\begin{array}{c}642(94.1 \%) \\
40(5.9 \%) \\
0(0.0 \%)\end{array}$ & 0.05 \\
\hline$+52289 \mathrm{~A}>\mathrm{G}$ & Intron 14 & & $\begin{array}{l}\text { A } \\
\text { AG } \\
\text { G }\end{array}$ & $\begin{array}{c}434(57.5 \%) \\
286(37.9 \%) \\
35(4.6 \%)\end{array}$ & $\begin{array}{c}418(61.4 \%) \\
229(3.6 \%) \\
34(5.0 \%)\end{array}$ & 0.57 \\
\hline ht1(TCAGAGTCGAA) & & & $\begin{array}{l}-/- \\
-/ h t 1 \\
\text { ht1/ht1 }\end{array}$ & $\begin{array}{l}140(18.1 \%) \\
344(44.4 \%) \\
290(37.5 \%)\end{array}$ & $\begin{array}{l}129(19.6 \%) \\
292(44.2 \%) \\
239(36.2 \%)\end{array}$ & 0.87 \\
\hline ht2(CCAGAGTCGAA) & & & $\begin{array}{l}-/- \\
-/ h t 2 \\
h t 2 / h t 2\end{array}$ & $\begin{array}{c}644(83.2 \%) \\
122(15.8 \%) \\
8(1.0 \%)\end{array}$ & $\begin{array}{c}525(79.6 \%) \\
128(19.4 \%) \\
7(1.1 \%)\end{array}$ & 0.48 \\
\hline
\end{tabular}


$+5193 \mathrm{G}>\mathrm{A}$ (Arg109Lys), was also weakly associated with BMI among nondiabetic controls (Table 3), i.e., the lowest BMI level $(23.44 \pm 2.96)$ was found among individuals homozygous for the major alleles $(\mathrm{G} / \mathrm{G}, \mathrm{Arg} /$ Arg), an intermediate level $(23.74 \pm 3.19)$ was measured among heterozygous subjects $(\mathrm{G} / \mathrm{A}, \mathrm{Arg} / \mathrm{Lys})$, and the highest level $(24.72 \pm 3.83)$ occurred among those homozygous for the minor allele (A/A, Lys/Lys) $(P=0.02$, Table 3$)$. As a result, we found that two polymorphisms, $+35861 \mathrm{~T}>\mathrm{C}(\mathrm{Ser} 343 \mathrm{Ser})$ in exon 8 and $+50416 \mathrm{~A}>\mathrm{G}$ in intron 13 , were marginally associated with increased risk of T2DM $(P=0.05$ and 0.05 , respectively, Table 2 ), and that one non-synonymous SNP in exon 3, +5193G $>$ A (Arg109Lys), was also weakly associated with BMI among nondiabetic controls (Table 3), i.e., the lowest BMI level $(23.44 \pm 2.96)$ was found among individuals homozygous for the major alleles $(\mathrm{G} / \mathrm{G}, \quad \mathrm{Arg} / \mathrm{Arg})$, an intermediate level $(23.74 \pm 3.19)$ was measured among heterozygous subjects (G/A, Arg/Lys), and the highest level (24.72 \pm 3.83$)$ occurred among those homozygous for the minor allele (A/A, Lys/Lys) $(P=0.02$, Table 3$)$. However, this nonsynonymous SNP was not associated with other clinical profiles such as waist/hip ratio, cholesterol, triglyceride, blood glucose level, HDL cholesterol, SBP (systolic blood pressure), DBP (diastolic blood pressure) and logtransformed HOMA-IR (see Table S4, Supplementary material). In addition, although not statistically significant $(P=0.06$, Table 3$),+27265 \mathrm{G}>\mathrm{A}$ (Arg223Gln) was also weakly associated with BMI.

\section{Discussion}

Research attempts to discover additional polymorphisms in important genes that may potentially be involved in major human diseases can provide valuable information for further genetic epidemiology study. It is well known that some SNPs in the NCBI database have

Table 3 Regression analyses for age- and sex-adjusted BMI with LEPR polymorphisms among nondiabetic subjects. $C / C, C / R, R / R$ Homozygotes for the common allele, heterozygotes and homozygotes for the rare allele, respectively. Genotype distribution, means, and standard deviation (SD) of BMI, and $P$-values for not been validated in population samples, although the content of the NCBI SNP database is rapidly updated though worldwide efforts such as the international HapMap project (http://www.hapmap.org/). LEP and its receptor, LEPR, may be among the most interesting and relevant genes for obesity studies. In this study, we identified 35 sequence variants in LEPR, including 9 novel polymorphisms and several SNPs, which have not been confirmed in population samples.

Although the potential effects of LEPR polymorphisms [in particular, +5193G $>$ A (Arg109Lys) and $+27265 \mathrm{G}>\mathrm{A}(\mathrm{Arg} 223 \mathrm{Gln})]$ on obesity have been evaluated in various populations, the genetic effects of LEPR on obesity phenotypes are still controversial. The non-synonymous SNP on exon 3, +5193G $>$ A (Arg109Lys), has been reported to be associated with BMI in the Swedish population (Rosmond et al. 2000), and with fasting insulin level in the Belgian population (Wauters et al. 2001). The +27265G > A (Arg223Gln), non-synonymous SNP on exon 5, has shown positive association with blood pressure (Rosmond et al. 2000), obesity, BMI, fat mass (Yiannakouris et al. 2001; Mattevi et al. 2002), cholesterol levels (Takahashi-Yasuno et al. 2003), insulin level, insulin sensitivity, and glucose clearance (Chiu et al. 2004; Guizar-Mendoza et al. 2005). However, one meta-analyses with nine studies on LEPR gene polymorphisms [ +5193G $>$ A (Arg109Lys) and $+27265 \mathrm{G}>\mathrm{A}(\mathrm{Arg} 223 \mathrm{Gln})]$ suggested that, although certain genotypic effects could be populationspecific, there was no statistically compelling evidence that either of the two LEPR alleles is associated with BMI in the overall population by heterogeneity tests, which showed that the variations of the non-significant effects were within the range of sampling variation (Heo et al. 2002).

In this study, we found that $+5193 \mathrm{G}>\mathrm{A}$ (Arg109Lys) on exon 3 was weakly associated with BMI among nondiabetic controls. The genetic effects of $+5193 \mathrm{G}>\mathrm{A}$ (Arg109Lys) in the Korean population were in accor-

regression analyses of the co-dominant model are shown. $P$-values of haplotype associations were calculated using the algorithm developed by Schaid et al. (Haplo.Score), while controlling for age and sex as covariates. Haplotypes with frequency $>0.05$ are presented

\begin{tabular}{|c|c|c|c|c|c|c|}
\hline Locus & Position & AA change & $\mathrm{C} / \mathrm{C}$ & $\mathrm{C} / \mathrm{R}$ & $\mathrm{R} / \mathrm{R}$ & $P$ \\
\hline$-141013 \mathrm{~T}>\mathrm{C}$ & Promoter & & $505(23.51 \pm 3.04)$ & $160(23.68 \pm 3.09)$ & $14(24.06 \pm 3.66)$ & 0.71 \\
\hline$-140259 \mathrm{C}>\mathrm{T}$ & $5^{\prime}$ UTR & & $629(23.56 \pm 3.06)$ & $49(23.69 \pm 3.13)$ & $1(23.3)$ & 0.78 \\
\hline$-186 \mathrm{~A}>\mathrm{G}$ & Intron 1 & & $541(23.51 \pm 3.03)$ & $135(23.72 \pm 3.09)$ & $5(25.78 \pm 5.41)$ & 0.17 \\
\hline$+5193 \mathrm{G}>\mathrm{A}$ & Exon 3 & Arg109Lys & $458(23.44 \pm 2.96)$ & $200(23.74 \pm 3.19)$ & $22(24.72 \pm 3.83)$ & 0.02 \\
\hline$+7187 \mathrm{~A}>\mathrm{C}$ & Intron 4 & & $485(23.51 \pm 3)$ & $183(23.58 \pm 3.11)$ & $13(25.36 \pm 4.36)$ & 0.17 \\
\hline$+27265 \mathrm{G}>\mathrm{A}$ & Exon 5 & Arg223Gln & $520(23.47 \pm 3.02)$ & $148(23.77 \pm 3.14)$ & $13(25.08 \pm 3.58)$ & 0.06 \\
\hline$+35861 \mathrm{~T}>\mathrm{C}$ & Exon 8 & Ser343Ser & $613(23.51 \pm 3.03)$ & $63(24.02 \pm 3.49)$ & $3(23.7 \pm 0.78)$ & 0.22 \\
\hline$+43285 \mathrm{C}>\mathrm{T}$ & Exon 11 & Asn567Asn & $673(23.57 \pm 3.06)$ & $7(23.11 \pm 4.14)$ & & 0.78 \\
\hline$+44704 \mathrm{G}>\mathrm{C}$ & Exon 13 & Lys656Asn & $593(23.6 \pm 3.05)$ & $84(23.32 \pm 3.2)$ & $3(22.73 \pm 3.18)$ & 0.43 \\
\hline$+50416 \mathrm{~A}>\mathrm{G}$ & Intron 13 & & $639(23.55 \pm 3.01)$ & $40(23.9 \pm 3.84)$ & & 0.36 \\
\hline$+52289 \mathrm{~A}>\mathrm{G}$ & Intron 14 & & $415(23.49 \pm 3.06)$ & $229(23.6 \pm 2.98)$ & $34(24.16 \pm 3.67)$ & 0.23 \\
\hline ht1(TCAGAGTCGAA) & & & & & & 0.06 \\
\hline ht2(CCAGAGTCGAA) & & & & & & 0.59 \\
\hline
\end{tabular}


dance with the study of the Swedish population, as increased BMI was found to be associated with Lys/Lys homozygotes (Rosmond et al. 2000). Likewise, $+27265 \mathrm{G}>\mathrm{A}(\mathrm{Arg} 223 \mathrm{Gln})$ showed a trend of genetic effects on BMI similar to the results from a Greek population study (Yiannakouris et al. 2001), i.e.., higher BMI among individuals with the Gln allele.

The genetic effects of $+5193 \mathrm{G}>\mathrm{A}$ (Arg109Lys) and $+27265 \mathrm{G}>\mathrm{A}(\mathrm{Arg} 223 \mathrm{Gln})$ on T2DM had been previously studied in the Finnish population (Santaniemi et al. 2004; Salopuro et al. 2005). Santaniemi et al. (2004) examined the genetic effect of $+27265 \mathrm{G}>\mathrm{A}$ (Arg223Gln) and found no association. On the other hand, Salopuro et al. (2005) reported that the Lys109 allele of $+5193 \mathrm{G}>\mathrm{A}$ (Arg109Lys) and the Gln223 allele of $+27265 \mathrm{G}>\mathrm{A}(\mathrm{Arg} 223 \mathrm{Gln})$ were associated with increased risk of T2DM. However, in the present study, we failed to replicate the association between $+5193 \mathrm{G}>\mathrm{A}$ (Arg109Lys) and $+27265 \mathrm{G}>\mathrm{A}$ (Arg223Gln) and T2DM in the Korean population. These divergent results may be due to the differences of ethnicity and/or study subjects.

Although our results that two polymorphisms $[+35861 \mathrm{~T}>\mathrm{C}($ Ser343Ser) in exon 8 and $+50416 \mathrm{~A}>\mathrm{G}$ in intron 13] were marginally associated with increased risk of T2DM $(P=0.05$ and 0.05 , respectively), could not retain significance after correction of multiple testing, further studies are needed to confirm the putative genetic association revealed in this study given the important function of this gene.

In summary, in an effort to determine the possible involvement of genetic polymorphisms of LEPR in BMI and T2DM, we have discovered 35 polymorphisms and genotyped 11 polymorphisms in the Korean population (775 T2DM patients and 688 normal subjects). Statistical analyses revealed that (1) the polymorphism $+5193 \mathrm{G}>\mathrm{A}$ (Arg109Lys) on exon 3 have marginal association with BMI among nondiabetic controls, and (2) two polymorphisms, $+35861 \mathrm{~T}>\mathrm{C}$ (Ser343Ser) in exon 8 and $+50416 \mathrm{~A}>\mathrm{G}$ in intron 13 , were weakly associated with increased risk of T2DM. Further biological and/or functional evidence would be needed to confirm the association of LEPR polymorphisms with T2DM and BMI suggested in this study.

Acknowledgements This work was supported by an intramural grant of the National Institute of Health, Korea, and a grant from the Korea Health 21 R \& D Project, Ministry of Health \& Welfare, Republic of Korea (00-PJ3-PG6-GN07-001).

\section{References}

Aiston S, Agius L (1999) Leptin enhances glycogen storage in hepatocytes by inhibition of phosphorylase and exerts an additive effect with insulin. Diabetes 48:15-20

Berti L, Kellerer M, Capp E, Haring HU (1997) Leptin stimulates glucose transport and glycogen synthesis in $\mathrm{C} 2 \mathrm{C} 12$ myotubes: evidence for a P13-kinase mediated effect. Diabetologia 40:606609
Bouchard C (1994) Genetics of obesity: overview and research directions. In: Bouchard C (ed) The genetics of obesity. CRC Press

Ceddia RB, William WN Jr, Curi R (1999) Comparing effects of leptin and insulin on glucose metabolism in skeletal muscle: evidence for an effect of leptin on glucose uptake and decarboxylation. Int J Obes Relat Metab Disord 23:75-82

Chiu KC, Chu A, Chuang LM, Saad MF (2004) Association of leptin receptor polymorphism with insulin resistance. Eur J Endocrinol 150:725-729

Cohen B, Novick D, Rubinstein M (1996) Modulation of insulin activities by leptin. Science 274:1185-1188

Considine RV, Sinha MK, Heiman ML, Kriauciunas A, Stephens TW, Nyce MR, Ohannesian JP, Marco CC, McKee LJ, Bauer TL, et al (1996) Serum immunoreactive-leptin concentrations in normal-weight and obese humans. N Engl J Med 334:292-295

Emilsson V, Liu YL, Cawthorne MA, Morton NM, Davenport M (1997) Expression of the functional leptin receptor mRNA in pancreatic islets and direct inhibitory action of leptin on insulin secretion. Diabetes 46:313-316

Friedman JM, Halaas JL (1998) Leptin and the regulation of body weight in mammals. Nature 395:763-770

Fukuda H, Iritani N, Sugimoto T, Ikeda H (1999) Transcriptional regulation of fatty acid synthase gene by insulin/glucose, polyunsaturated fatty acid and leptin in hepatocytes and adipocytes in normal and genetically obese rats. Eur $\mathbf{J}$ Biochem 260:505-511

Guizar-Mendoza JM, Amador-Licona N, Flores-Martinez SE, Lopez-Cardona MG, Ahuatzin-Tremary R, Sanchez-Corona J (2005) Association analysis of the Gln223Arg polymorphism in the human leptin receptor gene, and traits related to obesity in Mexican adolescents. J Hum Hypertens 19:341-346

Halaas JL, Gajiwala KS, Maffei M, Cohen SL, Chait BT, Rabinowitz D, Lallone RL, Burley SK, Friedman JM (1995) Weight-reducing effects of the plasma protein encoded by the obese gene. Science 269:543-546

Heo M, Leibel RL, Fontaine KR, Boyer BB, Chung WK, Koulu M, Karvonen MK, et al. (2002) A meta-analytic investigation of linkage and association of common leptin receptor (LEPR) polymorphisms with body mass index and waist circumference. Int J Obes Relat Metab Disord 26:640-646

Kieffer TJ, Heller RS, Habener JF (1996) Leptin receptors expressed on pancreatic beta-cells. Biochem Biophys Res Commun 224:522-527

Kieffer TJ, Heller RS, Leech CA, Holz GG, Habener JF (1997) Leptin suppression of insulin secretion by the activation of ATP-sensitive $\mathrm{K}+$ channels in pancreatic beta-cells. Diabetes 46:1087-1093

Livak KJ (1999) Allelic discrimination using fluorogenic probes and the $5^{\prime}$ nuclease assay. Genet Anal 14:143-149

Maffei M, Halaas J, Ravussin E, Pratley RE, Lee GH, Zhang Y, Fei H, Kim S, Lallone R, Ranganathan S et al (1995) Leptin levels in human and rodent: measurement of plasma leptin and ob RNA in obese and weight-reduced subjects. Nat Med 1:1155-1161

Mantzoros CS (1999) The role of leptin in human obesity and disease: a review of current evidence. Ann Intern Med 130:671680

Mantzoros CS, Flier JS (2000) Editorial: leptin as a therapeutic agent-trials and tribulations. J Clin Endocrinol Metab 85:4000-4002

Mattevi VS, Zembrzuski VM, Hutz MH (2002) Association analysis of genes involved in the leptin-signaling pathway with obesity in Brazil. Int J Obes Relat Metab Disord 26:11791185

Matthews DR, Hosker JP, Rudenski AS, Naylor BA, Treacher DF, Turner RC (1985) Homeostasis model assessment: insulin resistance and beta-cell function from fasting plasma glucose and insulin concentrations in man. Diabetologia 28:412-419

Pelleymounter MA, Cullen MJ, Baker MB, Hecht R, Winters D, Boone T, Collins F (1995) Effects of the obese gene product on body weight regulation in ob/ob mice. Science 269:540-543 
Rosmond R, Chagnon YC, Holm G, Chagnon M, Perusse L, Lindell K, Carlsson B, Bouchard C, Bjorntorp P (2000) Hypertension in obesity and the leptin receptor gene locus. J Clin Endocrinol Metab 85:3126-3131

Salopuro T, Pulkkinen L, Lindstrom J, Eriksson JG, Valle TT, Hamalainen H, Ilanne-Parikka P, Keinanen-Kiukaanniemi S, Tuomilehto J, Laakso M, Uusitupa M (2005) Genetic variation in leptin receptor gene is associated with type 2 diabetes and body weight: the Finnish diabetes prevention study. Int $\mathbf{J}$ Obes 29:1245-1251

Santaniemi M, Ukkola O, Kesaniemi YA (2004) Tyrosine phosphatase $1 \mathrm{~B}$ and leptin receptor genes and their interaction in type 2 diabetes. J Intern Med 256:48-55

Schaid DJ, Rowland CM, Tines DE, Jacobson RM, Poland GA (2002) Score tests for association between traits and haplotypes when linkage phase is ambiguous. Am J Hum Genet 70:425-434

Sivitz WI, Walsh SA, Morgan DA, Thomas MJ, Haynes WG (1997) Effects of leptin on insulin sensitivity in normal rats. Endocrinology 138:3395-3401

Takahashi-Yasuno A, Masuzaki H, Miyawaki T, Ogawa Y, Matsuoka N, Hayashi T, Hosoda K, Inoue G, Yoshimasa Y, Nakao K (2003) Leptin receptor polymorphism is associated with serum lipid levels and impairment of cholesterol lowering effect by simvastatin in Japanese men. Diabetes Res Clin Pract 62:169-175

Tartaglia LA, Dembski M, Weng X, Deng N, Culpepper J, Devos R, Richards GJ, Campfield LA, Clark FT, Deeds J, Muir C,
Sanker S, Moriarty A, Moore KJ, Smutko JS, Mays GG, Wool EA, Monroe CA, Tepper RI (1995) Identification and expression cloning of a leptin receptor, OB-R. Cell 83:1263-1271

The expert committee on the diagnosis and classification of diabetes mellitus (1997) Report of the expert committee on the diagnosis and classification of diabetes mellitus. Diabetes Care 20:1183-1197

Van Rossum CT, Hoebee B, van Baak MA, Mars M, Saris WH, Seidell JC (2003) Genetic variation in the leptin receptor gene, leptin, and weight gain in young Dutch adults. Obes Res 11:377-386

Wauters M, Mertens I, Rankinen T, Chagnon M, Bouchard C, Van Gaal L (2001) Leptin receptor gene polymorphisms are associated with insulin in obese women with impaired glucose tolerance. J Clin Endocrinol Metab 86:3227-3232

Woods AJ, Stock MJ (1996) Leptin activation in hypothalamus. Nature 381:745

Yiannakouris N, Yannakoulia M, Melistas L, Chan JL, KlimisZacas D, Mantzoros CS (2001) The Q223R polymorphism of the leptin receptor gene is significantly associated with obesity and predicts a small percentage of body weight and body composition variability. J Clin Endocrinol Metab 86:44344439

Zhang Y, Proenca R, Maffei M, Barone M, Leopold L, Friedman JM (1994) Positional cloning of the mouse obese gene and its human homologue. Nature 372:425-432 